\title{
Klasterisasi Manajemen Perkandangan Sapi Bali pada Simantri di Kabupaten Badung Bali
}

\author{
(CLUSTERING OF BALI CATTLE STALLING MANAGEMENT AT SIMANTRI IN \\ BADUNG REGENCY)
}

\section{Gusde Wahyu Krisna Suputra ${ }^{1 *}$, I Putu Sampurna², Tjokorda Sari Nindhia², Kadek Karang Agustina ${ }^{3}$}

1Jl. Bungtomo 1B, Perumahan Citra Garden View No. 4A, Denpasar Bali, Indonesia 80116; ${ }^{2}$ Laboratorium Biostatistika Veteriner, Fakultas Kedokteran Hewan, Universitas Udayana, Jl.

PB. Sudirman Denpasar, Bali, Indonesia 80225;

${ }^{3}$ Laboratorium Kesehatan Masyarakat Veteriner, Fakultas Kedokteran Hewan, Universitas Udayana, Jl. PB. Sudirman Denpasar, Bali, Indonesia 80225.

*Email: gusde.wahyu99@gmail.com

\begin{abstract}
ABSTRAK
Penelitian klasterisasi manajemen perkandangan sapi bali pada sistem pertanian terintegrasi (Simantri) di Kabupaten Badung, bertujuan untuk mengetahui komponen-komponen perkandangan sapi bali yang belum dilakukan secara intensif pada gabungan kelompok tani (Gapoktan) di Kabupaten Badung dan untuk mengetahui Gapoktan mana yang belum melakukan sitem perkandangan sapi bali secara intensif pada Simantri di Kabupaten Badung. Pengambilan sampel manajemen perkandangan sapi bali dilakukan secara teknik sampling jenuh. Data yang diperoleh dianalisis menggunakan Hierarchical cluster dengan Plot dendogram cluster dengan variabel penciri intensif, semi intensif, dan ekstensif. Hasil dari penelitian ini 42 dari 50 Simantri pada Gapoktan di Kabupaten Badung sudah menerapkan manajemen perkadangan secara intensif, komponen manajemen perkandangan yang sebagian besar dilakukan secara intensif meliputi: atap kandang, tempat pakan, tempat minum, lantai kandang, keadaan sekitar kandang, dan pembersihan kandang. Ada delapan Simantri yang manajemen perkandangan masih semi intensif. Komponen manajemen perkandangan yang masih diterapkan secara semi intensif adalah kebersihan kandang. Perlu dilakukan penyuluhan kepada anggota Simantri untuk membenahi manajemen permbersihan kandang.
\end{abstract}

Kata kunci: cluster; manajemen perkandangan; Simantri.

\begin{abstract}
Clustering study of bali cattle housing management in integrated farming system (Simantri) in Badung Regency aims to find out the components of bali cattle that have not been intensively carried out in group farmers (Gapoktan) in Badung Regency and to find out which Gapoktan has not conducted the Bali cattle intensive system in Simantri in Badung Regency. Sampling of bali cattle housing management was carried out by saturated sampling technique. The data obtained were analyzed by Hierarchical clusters with dendogram cluster plot with intensive, semi-intensive, and extensive identifying variables. The results showed that 42 out of 50 Simantri in Gapoktan in Badung District have an intensive management, stalling management components which are mostly carried out intensively include: cage roofs, food stalls, drinking places, cages, circumstances around the cage, and cage cleaning. There are 8 Simantri whose stalling management is still semi-intensive. The housing management component that is still applied semi-intensively was cage cleanliness. Counseling for Simantri members is needed to improve cage cleaning management.
\end{abstract}

Keywords: cluster; stalling management; Simantri. 


\section{PENDAHULUAN}

Sistem Pertanian Terintegrasi atau dikenal dengan Simantri telah menjadi model pembangunan pertanian daerah di Provinsi Bali. Program Simantri telah dilaksanakan pada tahun 2008-2013 dan kemudian dilanjutkan 2013-2018. Dalam satu kelompok Simantri terdiri atas 20 orang anggota Kelompok Tani dengan bantuan dari pemerintah berupa 1 unit kandang koloni, bibit induk sapi bali, fasilitas pengolahan pupuk organik (padat dan cair), pembuatan biogas serta pendampingan (Sudita et al., 2015). Simantri merupakan program unggulan bagi Pemerintah Provinsi Bali dengan target 1000 unit Simantri di tahun 2018 (Anugrah et al., 2014).

Sapi bali merupakan salah satu bangsa sapi asli Indonesia, yang merupakan keturunan dari banteng (Bibos banteng) yang telah mengalami proses domestikasi sebelum 3.500 SM, sapi bali memiliki karakteristik yang sama dengan banteng (Sampurna et al., 2017). Sapi bali merupakan sapi yang telah dipelihari turun menurun oleh petani di Bali, sapi bali juga digunakan untuk membajak sawah serta menghasilkan pupuk kandang yang digunakan oleh petani untuk menyuburkan tanah pertanian (Chamdi, 2005). Sapi bali juga memiliki kualitas adaptasi yang baik dengan lingkungan, tingkat pertumbuhan yang relatip cepat, dan penampilan reproduksi yang baik (Siswanto et al., 2013). Sapi bali memiliki kualitas karkas yang baik, kadar lemak rendah dan daging yang berkualitas baik, dan memiliki daya tahan yang baik terhadap infeksi parasit internal dan eksternal (Setiawan et al., 2014; Suwiti et al., 2017).

Kabupaten Badung merupakan salah satu kabupaten yang menjadi sentra pembibitan sapi lokal di Bali. Program dari Dinas Peternakan, Perikanan dan Kelautan Kabupaten Badung terus menggalakkan tentang pelestarian dan pengembangbiakan sapi bali pada 3 kecamatan di wilayah Badung, yaitu Petang, Abiansemal dan Mengwi. Dari tahun 2009 sampai akhir tahun 2016 di Kabupaten Badung telah terdapat 51 Simantri yang masih beroprasi dengan aktif (Dinas Tanaman Pangan Holtikultura dan Perkebunan Prov. Bali, 2016).

Kandang memiliki fungsi yang sangat penting dalam usaha sapi potong yaitu melindungi ternak dari perubahan cuaca atau iklim yang buruk, melindungi ternak dari pencurian, dan mencegah ternak terjangkit oleh suatu penyakit. Beberapa persyaratan yang perlu dipertimbangkan dalam pembuatan kandang sapi potong, secara teknis bernilai ekonomis, tidak berdampak negatif terhadap kesehatan ternak dan lingkungan sekitarnya serta dapat meningkatkan efisiensi pengelolaan (Rasyid et al., 2012).

Lokasi kandang yang perlu mendapatkan perhatian yaitu tersedianya sumber air, terutama untuk minum, dekat dengan sumber pakan, tersedia sarana transportasi yang memadai, hal ini terutama untuk pengangkutan bahan pakan dan pemasaran, areal yang tersedia dapat diperluas (Nurochmah dan Rachma, 2017). Letak bangunan kandang harus mempunyai permukaan yang lebih tinggi dari pada kondisi di sekelilingnya, sehingga terhindar dari genangan air dan mempermudah pembuangan kotoran, tidak berdekatan dengan bangunan umum atau perumahan penduduk, tidak mengganggu kesehatan lingkungan, agak jauh dengan jalan umum, air limbah tersalur dengan baik (Sarwono, 2003).

Analisis klaster adalah analisis statistik multivariat, bertujuan untuk mengetahui struktur data menjadi beberapa kelompok, sehingga dapat dibedakan perbedaan antar kelompok, atau dengan memisahkan kasus / objek menjadi beberapa kelompok dengan karakteristik yang berbeda antara satu kelompok dengan kelompok lainnya. Analisis ini sudah digunakan oleh Nugraha et al. (2017) untuk mengelompokkan sistem pemeliharaan anjing dan tingkat pemahaman masyarakat tentang rabies di Kabupaten Bangli, Nindhia et al. (2017) juga menggunakan klasterisasi untuk 
menglompokan sistem pemeliharaan anjing yang beresiko rabies di daerah yang dilaporkan nagatif rabies di Kabupaten Jembrana Bali. Sampurna et al. (2017) menggunakan untuk mengklasifikasikan sistem pemeliharaan babi bali. Laporan terkini, Parwata et al. (2019) menggunakan klasterisasi untuk mengelompokkan manajemen pengolahan limbah sapi bali pada Simantri di Kabupaten Badung Bali.

Pengelompokan komponen-komponen manajemen perkandangan yang diterapkan dalam simantri perlu dilakukan untuk mengetahui tingkat intensitas manajemen perkandangan yang diterapkan. Oleh sebab itu, penelitian berupa klasterisasi manajemen perkandangan pada Simantri di Gapoktan Kabupaten Badung ini dilakukan untuk tercapainya program Simantri yang sesuai.

\section{METODE PENELITIAN}

\section{Objek Penelitian}

Objek yang digunakan dalam penelitian ini yaitu 50 kelompok Simantri yang masih aktif beroperasi di Kabupaten Badung sejak tahun 2009-2016.

\section{Cara Pengumpulan Data}

Teknik pengumpulan data dalam penelitian ini yaitu dengan menggunakan kuisioner (angket), wawancara dan pengamatan secara langsung di lapangan. Data diambil dari 50 Simantri di Gapoktan Kabupaten Badung yang mencakup 3 kecamatan, yaitu Kecamatan Mengwi yang berjumlah 20 Simantri, Kecamatan Abiansemal yang berjumlah 18 Simantri dan Kecamatan Petang yang berjumlah 12 Simantri.

\section{Prosedur Penelitian}

Wawancara dilakukan secara terstruktur, dimana daftar pertanyaan sudah dibuat secara sistematis oleh peneliti.
Penyusunan daftar pertanyaan diawali dengan identitas responden, baru masuk ke dalam poin-poin yang sudah tertera pada kuisioner atau angket. Responden yang dipilih ketua simantri, ketua gapoktan, petugas pendamping simantri atau anggota simantri yang dirasa mampu untuk menjawab pertanyaan peneliti.

Daftar pertanyaan pada kuisiner dibuat dengan bentuk pertanyaan tertutup (close question) yang memberikan kesempatan responden untuk memilih jawaban yang telah peneliti siapkan.

\section{Analisis Data}

Analisis data yang diperoleh dianalisis dengan Hierarchical Cluster, dengan tiga variabel penciri yaitu intensif, semi intensif dan ekstensif. Klasterisasi tersebut terdiri dari baik (Intensif), sedang (Semi Intensif), buruk (Ekstensif) dengan skor masingmasing 1, 2, dan 3 (Sampurna et al., 2017).

\section{HASIL DAN PEMBAHASAN}

Analisis Hierarchical Cluster dengan variabel penciri intensif, semi intensif, dan ekstensif berdasarkan variabel komponen manajemen perkandangan data kuisoner yang diperoleh pada Simantri di Gapoktan Kabupaten Badung 42 dari 50 simantri di Gapoktan Kabupaten Badung sudah menerapkan manajemen perkandangan secara intensif dan 8 Simantri yang menerapkan manajemen perkandangan secara semi intensif, sedangkan untuk penerapan yang ekstensif tidak ada.

Komponen manajemen perkandangan yang dilakukan secara intensif meliputi atap kandang, tempat pakan, tempat minum, lantai kandang, keadaan sekitar kandang, dan pembersihan kandang. Sedangkan komponen manajemen perkandangan yang diterapkan secara semi intensif yaitu kebersihan kandang. 
Tabel 1. Hasil klasterisasi komponen manajemen perkandangan pada Simantri Kabupaten Badung Bali

\begin{tabular}{ll}
\hline Klasterisasi & Komponen Manajemen Perkandangan \\
\hline & Atap Kandang \\
& Tempat Pakan \\
Intensif & Tempat Minum \\
& Lantai Kandang \\
& Keadaan Sekitar Kandang \\
& Pembersihan Kandang \\
\hline Semi Intensif & Kebersihan Kandang \\
\hline Ekstensif & - \\
\hline
\end{tabular}

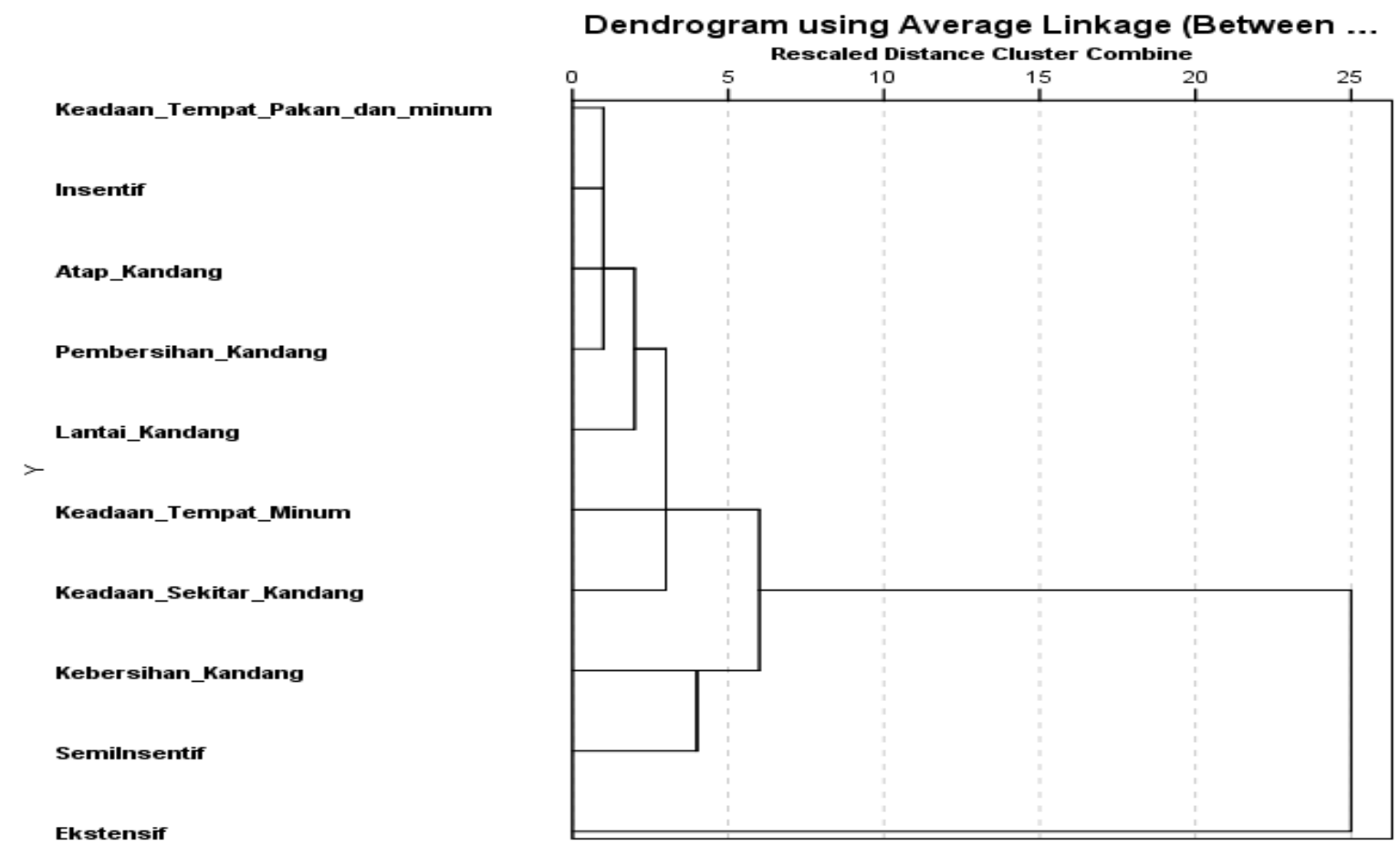

Gambar 1. Dendogram klasterisasi komponen manajemen perkandangan pada Simantri Kabupaten Badung Bali.

Tabel 2. Klasterisasi manajemen perkandangan pada Simantri Kabupaten Badung Bali.

\begin{tabular}{ll}
\hline Klasterisasi & \multicolumn{1}{c}{ Simantri } \\
\hline & Manik Tirta Rahayu, Gema Unggul Sari, KT Gema Makmur, Sejati, Sri \\
& Sedana, Kerta Buana Sari, KT Karya Mesari, Suka Maju, KT Banyusari, \\
& KTT Panca Urip Mertasari, Werdi buana, Dharma Pertiwi, Poktan Babakan \\
& Sari Sangeh, Gata Saga, KTT Mas Sari, KTT Sami Polih, KTT Catur Eka \\
& Sari, Pertiwi Tani,Taman Wijaya Kusuma, KTT buana mekar, Sari Lestari, \\
Intensif & KTT Bala Angon, KT Pula Kerti, Trimandala sari, Puncak Tedung Sari, \\
& KT Dewi Sari, KT Taman sari, Getasan, Sari Merta Pertiwi, Tedung Sari, \\
& KTT Darma Laksana, KT Dharma Karya, Kelompok Merta jaya, \\
& Branjungan, Karang ayu, Manik Eka Nadi, Cakra Buana, Pucaksari Bon, \\
& Wanasari, Gelis Nadi, KT Buana Giri, Tani Ternak Rare Angon, KT \\
& Gading Sari, dan Kerti Buana \\
\hline Semi Intensif & Merta Nadi, Mekar Sari, Merta Jati, Cakra Buana, Merta Bumi Sari, \\
& Tunjung, Amerta Jaya dan Manik Eka Nadi \\
\hline Ekstensif & -
\end{tabular}




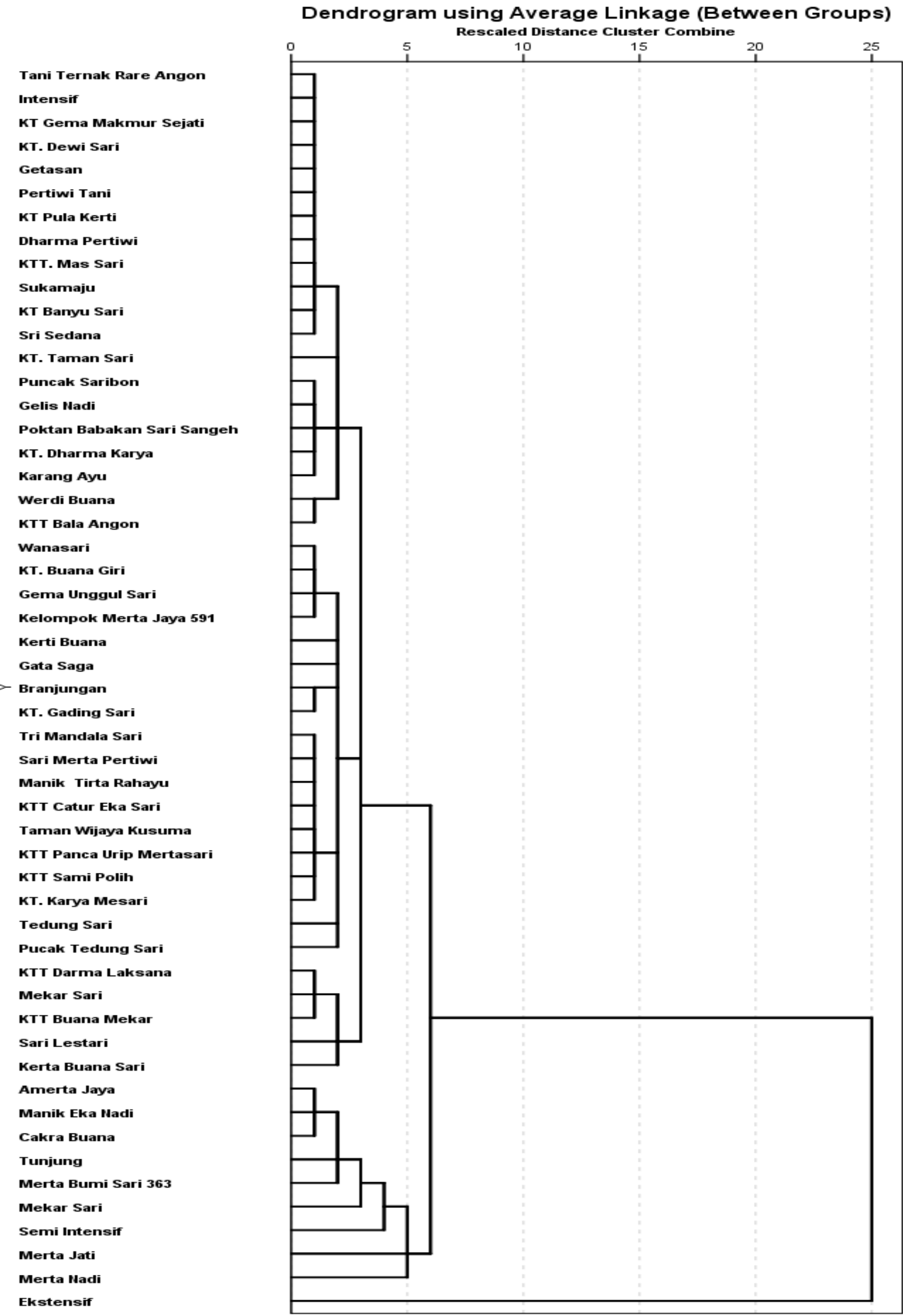

Gambar 2. Dendogram manajemen perkandangan pada Simantri Kabupaten Badung Bali. 
Hasil dari peragaan dendogram secara umum komponen manajemen perkandangan yang dilaksanakan secara intensif mencakup atap kandang, tempat pakan, tempat minum, lantai kandang, keadaan sekitar kandang, dan pembersihan kandang. Sedangkan tatalaksana manajemen perkandangan yang dilakukan secara semi intensif yaitu kebersihan kandang.

Perolehan hasil pengelompokan data manajemen perkandangan mengunakan analisis Hierarchical cluster dengan Plot dendogram cluster 42 dari 50 Simantri di Gapoktan Kabupaten Badung sudah menerapkan manajemen perkandangan yang bersifat intensif dan hanya 8 simantri yang manajemen perkandangannya diterapkan secara semi intensif. Hal ini disebabkan karena semua komponen perkandangan mendapat bantuan dari pemerintah Provinsi Bali.

Komponen-komponen manajemen perkandangan peternakan sapi yang menjadi prioritas tentu akan dilakukan secara intensif seperti kandang dan perlengkapannya. Kandang individu merupakan model kandang untuk satu ternak satu kandang, dimana pada bagian depan terdapat palungan dan bagian belakang terdapat selokan untuk pembuangan kotoran. Sapi pada kandang individu diikat dengan tali yang bertujuan untuk mencegah terjadinya perebutan makanan (Rasyid dan Hartati, 2007). Tipe kandang pada simantri Kabupaten Badung semuanya tipe kandang individu. Tipe kandang individu, dimana penempatan dalam satu baris kandang bisa di tempati oleh 5-10 ekor sapi. Pada Simantri Kabupaten Badung lantai kandang sudah semua diterapkan secara intensif dimana terbuat dari beton. Keunggulan lantai kandang dari beton yaitu akan memberikan kenyamanan pada sapi, lantai kandang tidak menjadi licin, dan lantai kandang akan tahan lama. Hal ini sesuai dengan pendapat bahwa pembuatan lantai kandang harus memenuhi syarat, dimana lantai kandang tidak licin, tidak mudah menjadi lembab, tahan pijakan, tahan lama, serta memberikan kenyamanan pada sapi baik pada saat berbaring maupun berdiri (Simamora et al., 2015)

Secara umum atap kandang dapat terbuat dari seng, asbes, genteng, dan rumbia (Yani dan Purwanto, 2006). Atap kandang pada Simantri di Kabupaten Badung atap kandang yang digunakan yaitu seng dan asbes, untuk daerah dataran tinggi seperti Kecamatan Petang Utara atap kandang sapi bali menggunakan bahan seng, karena seng memiliki kelebihan yang dapat menahan panas matahari, tetapi memiliki kelemahan dimana pada saat hujan akan menimbulkakan suara yang berisik. Sedangkan simantri pada daerah dataran rendah seperti Kecamatan Abiansemal dan Kecamatan Mengwi menggunakan bahan asbes karena kondisi cuaca lebih panas, yang bertujuan untuk menciptakan keadaan yang lebih sejuk di dalam kandang (Yani et al., 2007).

Keadaan tempat makan dan tempat minum pada Simantri Kabupaten Badung telah dilaksanakan secara intensif dimana terbuat dari semen cor. Hal ini sejalan dengan pernyataan Rasyid et al. (2012) untuk kandang individu sapi bali yang berukuran $150 \mathrm{~cm}$ lebar palungan atau tempat pakan yaitu $100 \mathrm{~cm}$, sedangkan lebar tempan minum berkisaran antara 50 $\mathrm{cm}$ yang terbuat dari semen cor (Aziz et al., 2013). Air merupakan hal yang amat penting dalam usaha peternakan (Schlink et al., 2011), dari penelitian yang dilakukan oleh peneliti pada Simantri Kabupaten Badung sudah tersedia air bersih untuk minum dan memandikan ternak. Sebagian besar pada simantri di Kabupaten Badung menggunakan sumber air yang berasal dari perusahaan air minum atau menggunakan air sungai.

Sebagian besar Simantri di Kabupaten Badung melakukan pembersihan kandang setiap 2 kali sehari, karena sebagian besar peternak memiliki kesibukan di luar program Simantri, peternak lebih sering melakukan pembersihan kandang pada pagi hari sebelum bekerja dan sore hari sepulang 
kerja, sehingga beberapa simantri di Kabupaten Badung kebersihan kandang masih dalam katagori semi intensif (Suharyati dan Hartono, 2016).

Keadaan di sekitar kandang Simantri Kabupaten Badung sudah termasuk dalam katagori intensif, dimana tersedia sarana transportasi yang memadai, di lokasikandang tersedia sumber pakan, dan jauh dari pemukiman penduduk atau bangunan umum, serta sirkulasi udara di dalam kandang lancar sehingga memberikan kenyamanan kepada ternak, peternak, maupun pengunjung Simantri (Suyasa et al., 2016).

Penerapan manajemen perkandangan secara intensif akan menguntungkan baik itu peternak dan hewan ternak, serta akan memberikan dampak yang positif terhadap lingkungan sekitar kandang (Bandara et al., 2011). Untuk tercapainya program Simantri yang maksimal perlu ditingkatkan pemahaman anggota tentang tatalaksana manajemen perkandangan yang baik agar dapat mengoptimalkan potensi yang dimiliki sapi bali, sehingga dapat membantu mensejahterakan anggota Simantri dan mendukung terlaksananya program Simantri yang sesuai.

\section{SIMPULAN}

Sebanyak 42 dari 50 Simantri di Gapoktan Kabupaten Badung Bali sudah menerapkan manajemen perkandangan yang bersifat intensif dan hanya delapan Simantri yang semi intensif. Komponen manajemen perkandangan yang belum diterapkan secara intensif pada Simantri di Gapoktan Kabupaten Badung yaitu kebersihan kandang.

\section{SARAN}

Untuk Simantri yang masih menerapkan manajemen perkandangan secara semi intensif perlu dilakukan penyuluhan kepada anggota Simantri untuk membenahi manajemen permbersihan kandang.

\section{UCAPAN TERIMAKASIH}

DOI: 10.24843/bulvet.2019.v11.i02.p04

Terimakasih penulis ucapkan kepada Gapoktan di Kabupaten Badung Bali yang telah memfasilitasi penelitian ini.

\section{DAFTAR PUSTAKA}

Anugrah IW, Sarwoprasodjo S, Suradisastra K, Purnaningsih N. 2014. Sistem pertanian terintegrasi-Simantri: Konsep, pelaksanaan dan perannya dalam pembangunan pertanian di Provinsi Bali. Forum Penelitian Agroekonomi. 32(2): 157-176.

Aziz AS, Surjowardojo P, Sarwiyon. 2013.

Hubungan bahan dan tingkat kebersihan lantai kandang terhadap kejadian mastitis melalui uji california mastitis test (cmt) di Kecamatan Tutur Kabupaten Pasuruan. J. Ternak Trop. 14(2): 72-81.

Bandara DMDS, Premaratne S, Dematawewa CMB. 2011. Production and economic characteristics of intensive and semi intensive dairy cattle management systems in vegetable based farming system in Welimada, Sri Lanka. Trop. Agric. Res. 22(3): 314323.

Chamdi AN. 2005. Karakteristik sumberdaya genetik ternak sapi bali (Bos-bibos Banteng) dan alternatif pola konservasinya. Biodiversitas. 6(1): 7075.

Dinas Tanaman Pangan, Holtikultura Dan Perkebunan Provinsi Bali. 2016. Program Sistem Pertanian Terintegrasi (Simantri) Provinsi Bali. Badung.

Nindhia TS, Batan IW, Sampurn IP, Prastya E. 2017. Clusterization of dog maintanence system that has risk of rabies in villages reported negative rabies in jembrana rengency. Studies on Bali Dog. Proc. Pp. 131-138.

Nugraha EY, Batan IW, Kardena IM. 2017. Sistem pemeliharaan anjing dan tingkat pemahaman masyarakat terhadap penyakit rabies di Kabupaten Bangli, Bali. J. Vet. 18(2): 274-282.

Nurochmah E, Rachma N. 2017. Hubungan sanitasi lingkungan dan jarak sumber 
air ke kandang sapi dengan kejadian diare di desa sruni kecamatan musuk Kabupaten Boyolali. J. Jur. Keperawatan. Pp. 1-8.

Parwata DMD, Sampurna IP, Sukada IM, Agustina KK. 2019. Klasterisasi manajemen pengolahan limbah sapi bali pada simantri di Kabupaten Badung. Bul. Vet. Udayana. 11(1): 5157.

Rasyid A, Hartati. 2007. Petunjuk teknis perkandangan sapi potong. Pusat Penelitian dan Pengembangan Peternakan Badan Penelitian dan Pengembangan Pertanian. Pp. 1-38.

Rasyid A, Efendi J, Mariyono. 2012. Sistem pembibitan sapi potong dengan kandang kelompok model Litbangtan. Badan Penelitian Dan Pengembangan Pertanian Kementerian Pertanian. Pp. $1-51$.

Sampurna IP, Nindhia TS, Sukada IM. 2017. Dendrogram simulations with determinatvariable identifer to determine the farm classification systems of bali pigs. Int. J. Sci. Res. 6(10): 1602-1606.

Sampurna IP, Nindhia TS. 2008. Analisis Data Dengan SPSS. $1^{\text {st }}$ Edisis Pertama. Udayana University Press.

Sarwono A. 2003. Produksi Ternak Sapi Potong. Penebar Swadaya. Jakarta.

Schlink AC, Nguyen ML, Viljoen GJ. 2011. Water requirements for livestock production: A global perspective. Soils Newsletter. 33(2): 6-7.

Setiawan H, Muhammad AID, Rahim L. 2014. Identifikasi tingkat kemurnian genetik sapi bali di Kabupaten Bone dengan menggunakan marker mikrosatelit lokus Inra035. Optimalisasi sumberdaya lokal pada peternakan lokal berbasis teknologi. Proc. Pp. 51-58.

Simamora T, Fuah AM, Atabany A, Burhanuddin. 2015. Evaluasi aspek teknis peternakan sapi perah rakyat di
Kabupaten Karo Sumatera Utara. J. Ilmu Prod. Teknol. Hasil Peternakan. 3(1): 52-58.

Siswanto M, Patmawati NW, Trinayani NN, Wandia IN, Puja IK. 2013. Penampilan reproduksi sapi bali pada peternakan intensif di Instalasi Pembibitan Pulukan. J. Ilmu Kes. Hewan. 1(1): 11-15.

Sudita IDN, Mahardika IG, Suarna IW, Gaga Partama IB. 2015. Analysis of feed for digestibility bali cow in group "Simantri" program in Bali on different topographic. Int. J. Adv. Sci. Eng. Infor. Technol. 5(6): 495-500.

Suharyati S, Hartono M. 2016. Pengaruh manajemen peternak terhadap efesiensi reproduksi sapi bali di Kabupaten Pringsewu Provinsi Lampung. J. Penelitian Pertanian Terapan. 16(1): 61-67.

Suwiti NK, Besung INK, Mahardika GN. 2017. Factors influencing growth hormone levels of Bali cattle in Bali, Nusa Penida, and Sumbawa Islands, Indonesia. Vet. World. 10(10): 12501254.

Suyasa IKG, Sarini NP, Lindawati SA. 2016. Penerapan manajemen pencegahan penyakit di peternakan F4S Mupu Amerta, Banjar Sale, Desa Abuan, Bangli. J. Trop. Anim. Sci. 4(1): 1-6.

Yani A, Purwanto BP. 2006. Pengaruh iklim mikro terhadap respons fisiologis sapi peranakan Fries Holland dan modifikasi lingkungan untuk meningkatkan produktivitasnya (ULASAN). Med. Peternakan. 29(1): 35-46.

Yani A, Suhardiyanto H, Hasbullah R, Purwanto BP. 2007. Analisis dan simulasi distribusi suhu udara pada kandang sapi perah menggunakan computational fluid dynamics (CFD). Med. Peternakan. 30(3): 218-228. 